
\title{
25 Research Soure \\ Fatal Sickling Associated Microvascular Occlusive Crisis in a Young Military Recruit with Sickle Cell Trait: A Case Report
}

Deepti Mutreja ( $\nabla$ deeptimutreja@gmail.com )

Armed Forces Medical College https://orcid.org/0000-0001-6274-4863

Benjith Paul K

Command Hospital Air Force Bangalore

Tilak T V S V G K

Armed Forces Medical College Pune

Vanmalini Tewari

Command Hospital Air Force Bangalore

\section{Case Report}

Keywords: Sickle cell trait, post-mortem, military recruit, severe exertion

Posted Date: August 5th, 2020

DOI: https://doi.org/10.21203/rs.3.rs-49020/v1

License: (c) (i) This work is licensed under a Creative Commons Attribution 4.0 International License. Read Full License 


\section{Abstract \\ Background.}

Sickle cell trait(SCT), a heterozygous state characterized by the presence of hemoglobin AS, occurs in varied frequency in the Indian population with highest prevalence in Central and southern India. SCT is compatible with a normal lifespan and not commonly regarded as a cause of morbid illness or death in contrast to sickle cell disease, its homozygous counterpart.

\section{Case Presentation.}

We describe a case of fatal sickling associated microvascular crisis, identified on post mortem evaluation in a previously undiagnosed 20-year-old military recruit with sickle cell trait. The individual presented with repeated episodes of presyncope during his training and was evaluated for cardiac anomalies and heat syncope. During the terminal episode, he collapsed and died of severe metabolic complications as he struggled to complete an organised run during routine training activities.

\section{Conclusion.}

To our knowledge, this is the first report of fatal sickling associated crisis in a military recruit with sickle cell trait from India. This case serves to remind all medical officers of the armed forces of the importance of screening a recruit who is unable to complete exertional physical training for the presence of sickle cell trait.

\section{Introduction}

Normal hemoglobin $(\mathrm{Hb})$ in adults is composed of $\mathrm{HbA}$ and $\mathrm{HbA}_{2}$ with small quantities of $\mathrm{HbF}$. Hemoglobin $\mathrm{S}(\mathrm{HbS})$, astructural hemoglobinopathy, in the heterozygous state, known as sickle cell trait(SCT), represented as $\mathrm{HbAS}$, it is marked by presence of $30-40 \%$ of $\mathrm{HbS}$ and the remainder being normal $\mathrm{HbA} .{ }^{1}$ This hemoglobinopathy is fairly common in India, especially in the malaria endemic belt of Orissa and Andhra Pradesh with its prevalence ranging from $1-40 \%$ in southern India. ${ }^{2}$

Although considered a benign haematological condition compatible with a normal lifespan, sickling associated fatal complications in a SCT have rarely been described in African-American recruits and athletes associated with severe physical exertion. ${ }^{3-5}$ Additional causes such as dehydration, heat stress, viral illness and poor physical training have been presumed to play a role. ${ }^{6}$ In this report we present the post mortem findings of a young military recruit, an undiagnosed case of SCT, who died of fatal sickling associated microvascular complications following an organised run during training activities. To our knowledge, this is the first report of this kind from India. 


\section{Case Presentation}

A 20-year-old recruit, resident of north coastal Andhra Pradesh, a known sickle cell belt of India, was brought to the emergency with alleged history of collapse and sudden loss of consciousness following a 2.2-kilometre organised run during routine training activities. There was history of non-recordable blood pressure and pulse following which the regimental medical officer had administered chest compressions. On evaluation, patient was found to be unresponsive, hyperventilating with no spontaneous eye opening and no response to pain. Pupils were bilaterally equal with a sluggish response to light. Pulse was $100 / \mathrm{min}$, BP was $110 / 60$ and respiratory rate was $42 / \mathrm{min}$.

Systemic examination revealed normal cardiovascular and chest findings. An arterial blood gas analysis showed profound anion gap metabolic acidosis $(\mathrm{pH} 6.61$, lactate 24.59 , anion gap $30.4 \mathrm{mmol} / \mathrm{L}, \mathrm{HCO} 3$ $4 \mathrm{mmol} / \mathrm{L}, \mathrm{pCO} 241.4 \mathrm{mmHg}$, sPO2 94\%). Random blood sugar was $246 \mathrm{mg} / \mathrm{dL}$. An electrocardiogram (ECG) showed features of hyperkalemia. Revaluation in the intensive care unit showed a disoriented patient with tense tender abdomen and decreased bowel sounds. Despite fluid resuscitation, patient continued to be anuric. A plain roentgenogram of abdomen showed grossly dilated stomach with distended bowel loops. Contrast enhanced computed tomogram of abdomen showed acute cortical necrosis of the kidneys with features of paralytic ileus. A urgent bedside 2D echogram was normal. Investigations revealed normal $\mathrm{Hb}$, elevated total leucocyte counts, deranged coagulation profile, hyperkalemia, markedly elevated liver enzymes, lactate dehydrogenase and creatine kinase(Table 1). Patient was managed with continuous renal replacement therapy. However, he desaturated, had a cardiac arrest and died 18 hours after admission.

On perusal of medical documents of the individual, it was found that in the past, there had been history of two similar episodes. The patient had presented with presyncope following organised battle preparedness efficiency test(BPET) as a part of military training. He had been hospitalised following one such episode during which tall T waves on ECG and hyperkalemia had been documented. However, his cardiac evaluation including electrocardiogram, Holter and treadmill test had been normal.

\section{Post mortem Findings}

An autopsy revealed the body of a young male with a normal frame. Fine adhesions were seen between the lung and the pleura on the left side. The lower lobes of both lungs were congested and oozed pink fluid. The peritoneal cavity contained minimal blood stained fluid. The small intestine showed marked congestion with two gangrenous segments measuring $15 \mathrm{~cm}$ and $7 \mathrm{~cm}$ (Fig. 1). Stomach showed hemorrhagic mucosal surface. Bilateral iliopsoas hematomas were seen and a large left subdural haemorrhage was seen on opening the cranial cavity. Spleen was enlarged measuring $350 \mathrm{~g}$ and showed congested cut surface. No splenic infarcts were seen. Cut surface of the brain parenchyma, heart, both kidneys, liver, adrenals, pancreas, urinary bladder and testes and were unremarkable on gross.

On microscopy, acute congestion and microvascular occlusion by sickled red cells was seen in the glomerular capillaries, hepatic sinusoids, splenic red pulp, brain,(Figs. 2a-d), pancreatic vasculature, 
adrenals, intestines, lymph nodes, and skeletal muscle. Pleural fibrosis was seen. Alveolar spaces of lower lobes showed congestion. Kidneys showed proximal tubular necrosis. Sections of skeletal muscle showed myonecrosis. There was no histopathologic evidence of any inflammatory or infectious disease.

Postmortem high performance liquid chromatography (HPLC) performed on deceased blood revealed $\mathrm{SCT}(\mathrm{HbS} 38.5 \%, \mathrm{HbA} 58.2 \%, \mathrm{HbA} 22.4 \%$ and $0.9 \% \mathrm{HbF}$ ). A similar pattern was seen in his father's blood. Death was attributed to multiorgan damage associated with massive intravascular sickling due to exertion induced hypoxia related with extreme physical activity and in an undiagnosed case of SCT.

\section{Discussion}

Sickle cell trait, although believed to be an innocuous condition is associated with certain clinical sequelae with increased frequency. These include isosthenuria, renal hematuria, bacteriuria and pyelonephritis in pregnancy, and splenic infarction with high altitude hypoxia. ${ }^{7}$ Sickle cell hemoglobinopathy is common in India but sudden death after physical exertion has never been reported. The Indian armed forces do not have a policy for screening recruits at entry for hemoglobinopathies nor is there a neonatal mass screening in India.

Many authors have cited that other factors in SCT such as intensity of exercise, dehydration, associated viral illnesses, heat stress and high altitude have a role in the trigger for collapse and sudden death. Of all these, intensity of exercise appears to be strongest incriminating factor. $4,5,6,8$ The deceased in this report had completed four months of military training and had already reported three episodes of exertional collapse, the final one being fatal. This is because during the course of military training the intensity of exercise is gradually increased. The instructor urges the recruits to go on to achieve their maximal limits of physical exertion. Social factors such as peer pressure may also be responsible for a military recruit to push himself to go on. Maximal physical effort results in hypoxemia, hyperthermia and lactic acidosis within the muscles. This leads to red cell dehydration as they pass through the hyperosmotic environment of the muscles. The outcome is concentration of the $\mathrm{HbS}$, resulting in sickling in the microcirculation. ${ }^{8}$ Low level of oxygenation in the cell is the prime physiologic cause of intravascular sickling in those with SCT. ${ }^{9}$

Repeated episodes of sickling may lead to local necrosis in the renal papillae, resulting in isosthenuria (the inability to concentrate urine), and consequent dehydration. ${ }^{9}$ It also contributes to the release of proinflammatory cytokines and procoagulant factors. ${ }^{10}$ The cumulative effects of all these factors in the bloodstream may have led to the development of an irreversible 'metabolic storm' like situation in this case.

At previous admissions the presyncope in this young recruit was misconstrued to cardiac causes and an extensive cardiac evaluation done was normal. Exertional heat related illness was another differential diagnosis. However, the area of the training centre is located at a mean height of 3000 feet above sea 
level and does not experience temperatures beyond 22 degrees in the morning hours even during summer months.

In a large study of 139 cases of non-traumatic exercise related deaths in recruits, the commonest cause of death cited were cardiac causes $(59 \%)$ namely coronary artery anomalies, myocarditis, atherosclerotic cardiovascular disease, and cardiomyopathy. Exertional heat injury was contributory to death in one third

of all cases and SCT was identified in $26(18.7 \%)$ of all cases. ${ }^{11}$ A retrospective review by Kark et al it had concluded that the risk of unexplained sudden death in African recruits with sickle cell trait was 30 times more than those without SCT. Most deaths had occurred during the initial months of training and were associated with physical activities involving maximal exertion. ${ }^{3}$

SCT is diagnosed by ion exchange HPLC. The peripheral blood and $\mathrm{Hb}$ values are usually normal in a SCT. Tests for sickling such as sodium metabisulfite tests can easily be performed in smaller laboratories. Till the advent of a neonatal screening program or screening for SCT at entry into the armed forces, if an individual has normal hematological values at entry to army, like in this case, it is impossible to diagnose a hemoglobinopathy.

\section{Conclusion}

As demonstrated in this case and other reports in literature, severe exertion can cause sickling and microvascular occlusion in a SCT also. A high index of suspicion and awareness to prevent crisis is required. Until universal screening policy comes into force, this case serves to remind all medical officers of the armed forces of the importance of screening a recruit who is unable to complete his BPET for the presence of SCT.

\section{Declarations}

\section{Ethics approval and consent to participate}

It is certified that ethical approval of ethics committee of Command Hospital Air Force Bangalore and consent of next of kin of deceased was sought prior to publication of this study

\section{Consent for publication}

It is certified that written informed consent of next of kin of deceased was sought prior to the post mortem study and publication of this study. The same is available with us for review by Editor of this journal.

\section{Availability of data and materials}

Not applicable.

\section{Competing interests}


The authors declare that they have no competing interests.

\section{Funding}

Not applicable

\section{Authors' contributions}

"DM, VT and BPK performed the post mortem examination of the individual, interpreted the patient data regarding the clinicopathological correlation of cause of death. TVSVGKT was involved in clinical patient management prior to his demise and shared the clinical data. DM and BPK performed the histological examination of the sections, and DM and TVSVGKT were major contributors in writing the manuscript. All authors read and approved the final manuscript."

\section{Acknowledgements}

"Not applicable"

\section{References}

1. Pearson HA. Sickle cell trait and competitive athletics: is there a risk?. Pediatrics. 1989;83(4):613-14.

2. Balgir RS. Genetic epidemiology of the three predominant abnormal hemoglobins in India. $J$ Assoc Physicians India. 1996;44(1):25-28.

3. Kark JA, Posey DM, Schumacher HR, Ruehle CJ. Sickle-cell trait as a risk factor for sudden death in physical training. N Engl J Med. 1987;317(13):781-7.

4. Anzalone ML, Green VS, Buja M, Sanchez LA, Harrykissoon RI, Eichner Sickle cell trait and fatal rhabdomyolysis in football training: a case study. Med Sci Sports Exerc. 2010;42(1):3-7.

5. Thogmartin JR, Wilson Cl, Palma NA, Ignacio SS, Shuman MJ, Flannag an LM. Sickle cell traitassociated deaths: a case series with a review of the iterature. J Forensic Sci. 2011;56(5):1352-60.

6. Weisman IM, Zeballos RJ, Martin TW, Johnson Effect of Army basic training in sickle-cell trait. Arch Intern Med 1988;148(5):1140-1144.

7. Sears The morbidity of sickle cell trait: a review of the literature. Am J Med. 1978 Jun;64(6):1021-36.

8. Eichner Sickle cell trait in sports Curr Sports Med Rep. 2010;9(6):347 -51.

9. Mitchell BL. Sickle cell trait and sudden death--bringing it home. J Natl Med Assoc. 2007;99(3):300305.

10. Connes P, Reid H, Hardy-Dessources MD, Morrison E, Hue Physiological responses of sickle cell trait carriers during exercise. Sports Med. 2008;38(11):931-46.

11. Scoville SL, Gardner JW, Magill AJ, Potter RN, Kark Nontraumatic deaths during U.S. Armed Forces basic training, 1977-2001. Am J Prev Med. 2004;26(3):205- 


\section{Tables}




\begin{tabular}{|c|c|c|c|}
\hline \multirow[t]{2}{*}{ Investigation( Normal range) } & \multirow{2}{*}{$\begin{array}{l}\text { Previous } \\
\text { hospitalisation( One } \\
\text { month ago) }\end{array}$} & \multicolumn{2}{|c|}{ Present hospitalisation } \\
\hline & & 0900h & 1430h \\
\hline $\mathrm{Hb}(14-18 \mathrm{~g} / \mathrm{dL})$ & 14.5 & 12.5 & 10.7 \\
\hline 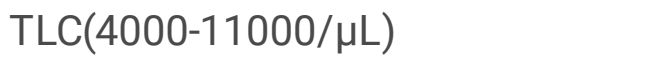 & 13600 & 27400 & 5700 \\
\hline Differential leucocyte count(\%) & $\mathrm{P}_{85} \mathrm{~L}_{9} \mathrm{M}_{5} \mathrm{E}_{1}$ & $\mathrm{P}_{79} \mathrm{~L}_{28} \mathrm{M}_{2} \mathrm{E}_{1}$ & $\mathrm{P}_{86} \mathrm{~L}_{10} \mathrm{M}_{1} \mathrm{E}_{1}$ \\
\hline Platelets $\left(150-400 \times 10^{3} / \mu \mathrm{L}\right)$ & 327 & 150 & 170 \\
\hline Blood sugar(random)(mg/dL) & 96 & 174 & \\
\hline BUN(7-23mg/dL) & 10 & 15 & 25 \\
\hline Creatinine(0.6-1.3mg/dL) & 1.3 & 0.6 & 2.1 \\
\hline Sodium(135-145 mmol/L) & 141 & 144 & 135 \\
\hline Potassium(3.5-5.3mmol/L) & 5.0 & 6.8 & 8.3 \\
\hline Chloride(97-110 mmol/L) & 106 & 103 & 108 \\
\hline Bilirubin(total/direct)(mg/dL) & $1.1 / 0.4$ & $1.1 / 0.6$ & $1.4 / 0.7$ \\
\hline $\begin{array}{l}\text { Aspartate aminotransferase } \\
(<40 \mathrm{U} / \mathrm{L})\end{array}$ & 75 & 108 & 2434 \\
\hline $\begin{array}{l}\text { Alanine } \\
\text { aminotransferase }(<40 \mathrm{U} / \mathrm{L})\end{array}$ & 98 & 127 & 1295 \\
\hline Cholesterol/TG & & $124 / 170$ & \\
\hline Proteins $(6-8 \mathrm{~g} / \mathrm{dL})$ & & 7.2 & 5.2 \\
\hline Albumin(3.5-4.8g/dL) & & 4.4 & 3.3 \\
\hline $\begin{array}{l}\text { Lactate Dehydrogensae(110- } \\
240 I U / L)\end{array}$ & - & 250 & 668 \\
\hline Prothrombin time)(11-15 seconds) & - & $12.5 / 21.6$ & $12.5 / 23.6$ \\
\hline (Control/Test) & & 1.68 & 1.85 \\
\hline \multicolumn{4}{|l|}{ INR } \\
\hline $\begin{array}{l}\text { Partial thromboplastin time } \\
\text { (Control/Test)(25-35 seconds) }\end{array}$ & - & $29 / 47.8$ & $29 / 52.3$ \\
\hline lonised calcium & 4.5 & - & - \\
\hline CPK(IU/L) & - & 27 & 1504 \\
\hline CKMB(IU/L) & & & 154 \\
\hline Peripheral Smear & & Normocytic & \\
\hline
\end{tabular}


normochromic

anemia,

Neutrophil

leucocytosis

Urine routine/microscopy

Protein 1+

6-8 pus cells/hpf

$\mathrm{HIV} / \mathrm{HBsAg} / \mathrm{HCV}$

Negative

Blood culture

Sterile after $72 \mathrm{~h}$

\section{Figures}

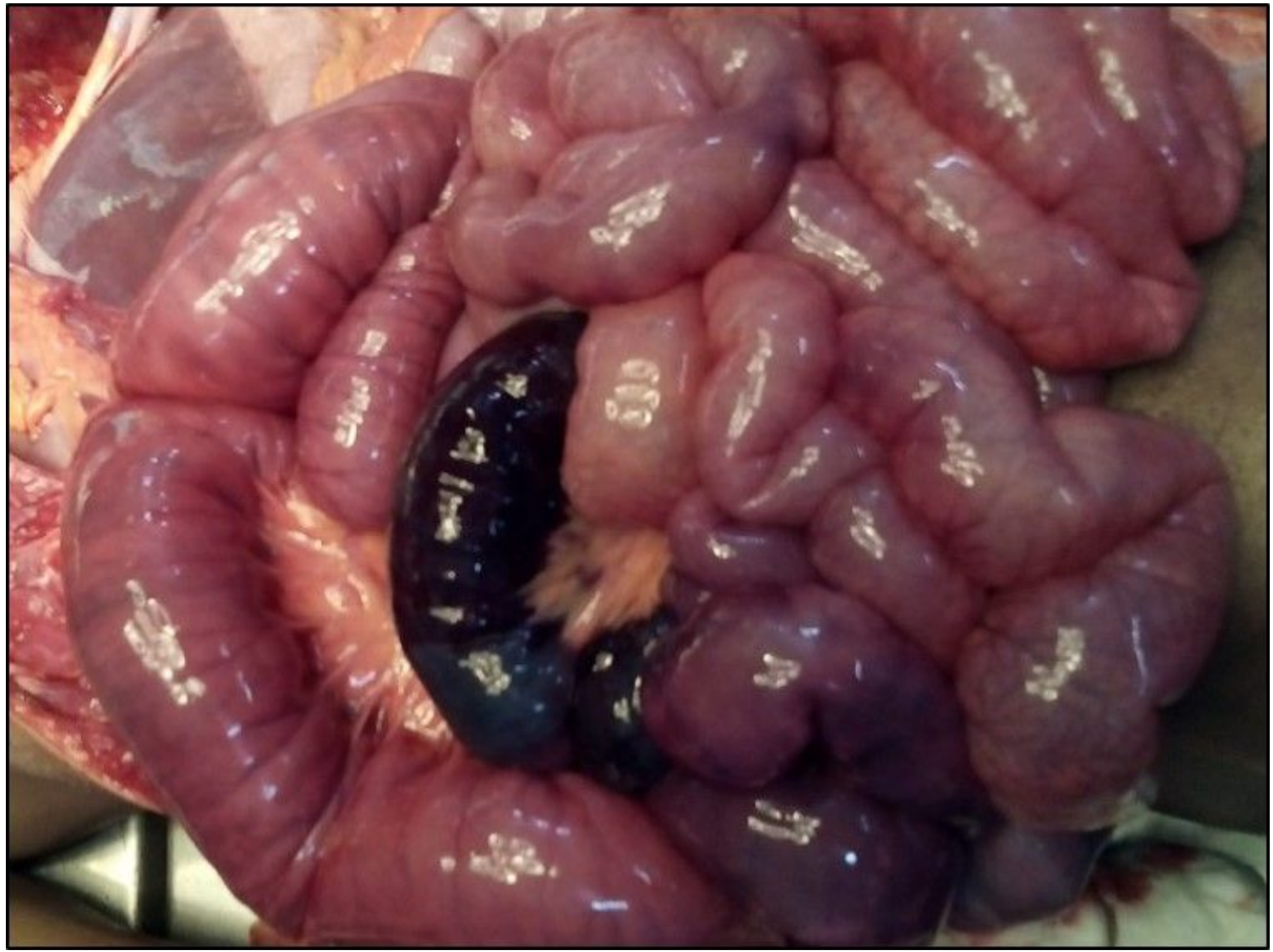

\section{Figure 1}

Gross picture of the small intestines showing marked congestion and a gangrenous segment 


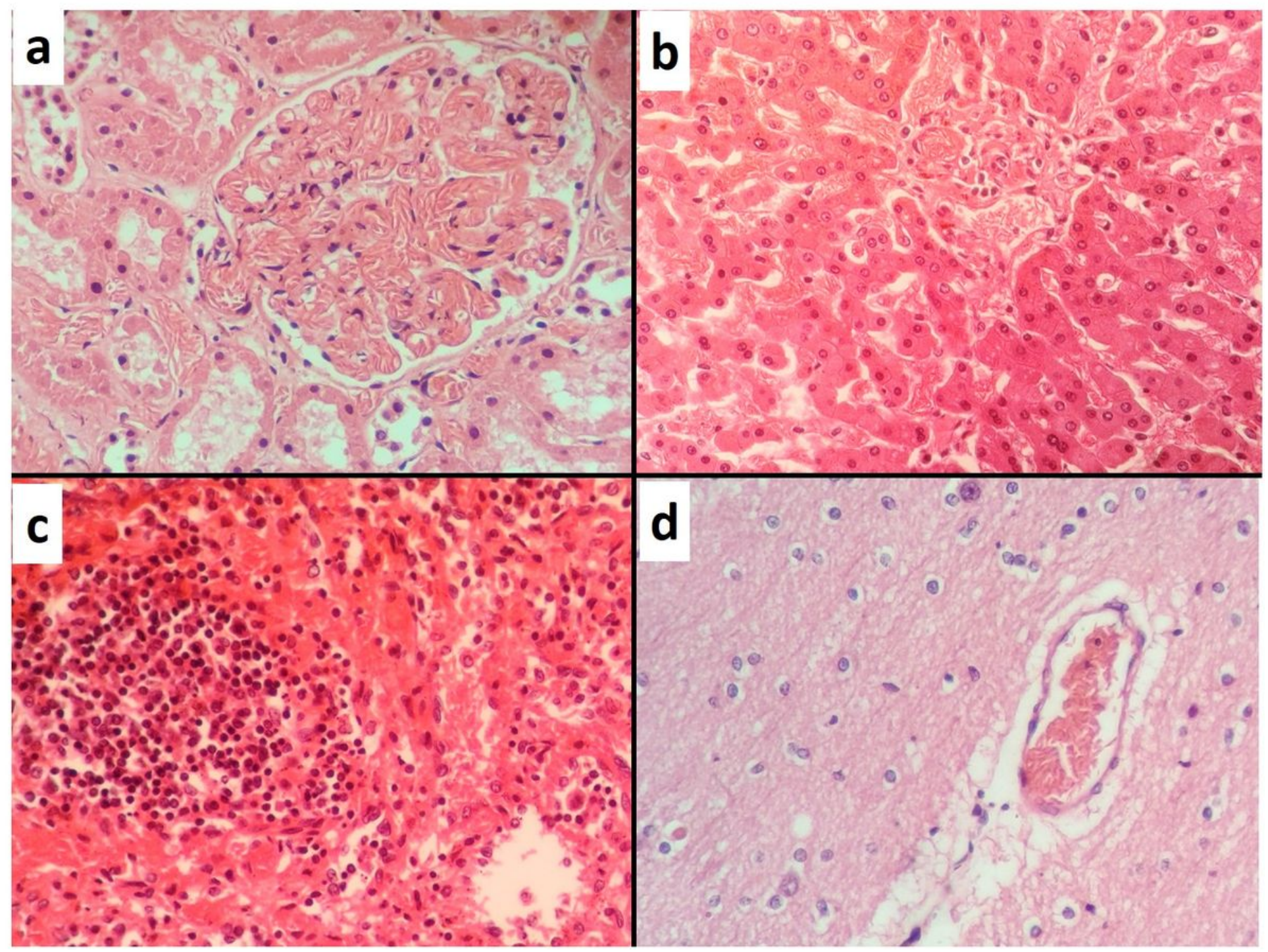

Figure 2

(Figure 2a): Histopathologic section of kidney showing sickled red blood cells clogging glomerular capillaries. (Figure 2b): Liver showing hepatic sinusoids congested with sickled red cells.( Figure 2c): Section of spleen showing microvascular occlusion within the capillaries and congestion of red pulp by sickled red cells . (Figure 2d): Cerebral capillaries showing sickled red cells. ( H\&E, 400x). 